\title{
KEANEKARAGAMAN JENIS TUMBUHAN BAWAH TANAMAN AKASIA (Acacia mangium Willd) DI BUKIT PENGHIJAUAN MANDOR KABUPATEN LANDAK
}

\author{
(Understoreys Diversity of Acacia plants (Acacia mangium Willd) in Bukit Penghijauan \\ Mandor Landak District)
}

\author{
Teodora Goreti, Abdurrani Muin, Burhanuddin \\ Fakultas Kehutanan Universitas Tanjungpura. Jalan Daya Nasional Pontianak 78124 \\ E-mail : teodoragoreti@gmail.com
}

\begin{abstract}
Acacia mangium plantations in Bukit Penghijauan has grown by various species of understoreys. This study aims are to examine uderstoreys diversity and determine the amount of species and dominant of understoreys that's growing under Acacia stands in Bukit Penghijauan Mandor Landak District. The study used a survey method with a systematic sampling of squares. Laying of plots was carried out by purposive sampling in area where are acacia plants. The size of plot is $10 \mathrm{~m} \times 10 \mathrm{~m}$, devided in to 25 sample plots of size $2 \mathrm{~m} \times 2 \mathrm{~m}$. Prymary data on taken involve species name, amount of individuals each species and herbarium specimens as identification device. The study result swowed that understoreys that be discovered under acacia stands in Bukit Penghijauan Mandor Landak District as much 21 species. The domination that species is paku resam (Gleichenia linearis Burm Clarke), rumput bede (Paspalum conjugatum Berg) and akar rambat (Psychotria sarmentosoides).
\end{abstract}

Keywords : Bukit penghijauan, Species diversity, Understoreys.

\section{Abstrak}

Areal tanaman Acacia mangium yang ditanam di Bukit Penghijauan Mandor telah ditumbuhi oleh beragai spesies tumbuhan bawah. Penelitian ini bertujuan untuk mengkaji keanekaragamaan jenis tumbuhan bawah dan menentukan jumlah jenis dan dominan tumbuhan bawah yang tumbuh di bawah tegakan akasia di Bukit Penghijauan Mandor Kabupaten Landak. Penelitian ini menggunakan metode survei dengan pengambilan petak contoh kuadrat yang diletakkan secara sistematis. Peletakan petak dilakukan dengan cara purposive sampling yaitu pada areal yang ada tanaman akasia. Ukuran petak adalah $10 \mathrm{~m} \times 10 \mathrm{~m}$, dibagi ke dalam 25 plot contoh ukuran $2 m \times 2 \mathrm{~m}$. Data primer yang diambil meliputi nama jenis, jumlah individu tiap jenisnya dan spesimen herbarium sebagai alat bantu identifikasi. Hasil penelitian menunjukkan bahwa tumbuhan bawah yang ditemukan di bawah tegakan akasia di Bukit Penghijauan Mandor Kabupaten Landak sebanyak 21 jenis. Jenis yang mendominasi adalah paku resam (Gleichenia linearis Burm Clarke), rumput bede (Paspalum conjugatum Berg) dan akar rambat (Psychotria sarmentosoides).

Kata Kunci : Bukit Penghijauan, Keanekaragaman jenis, Tumbuhan Bawah.

\section{PENDAHULUAN}

Bukit Penghijauan di Desa Mandor Kabupaten Landak dengan luas 54 ha terletak pada ketinggian $62,3 \mathrm{~m}$ dpl. Berbagai jenis tanaman terdapat di bukit ini seperti akasia, sengon dan tanaman buah-buahan yang ditanam pada program penghijauan sejuta pohon pada tahun 1993. Tanaman yang dominan di Bukit Penghijauan adalah Acacia mangium willd. Jenis tanaman akasia ini dianggap sebagai salah satu spesies invasif yang tersebar diberbagai daerah di dunia, termasuk negara-negara tropis di Asia 
Tenggara. Jenis atau spesies invasif mempunyai berbagai karakter yang kesemuanya bersifat kuat, namun cenderung negatif. Tumbuhan invasif tidak toleran dengan kehidupan jenis lainnya, sehingga cenderung dominan dalam menguasai suatu wilayah (ekosistem) yang baru didatangi serta secara umum sulit dikendalikan (Sutedjo dan Warsudi, 2017).

Daun akasia diketahui mengandung alelopati yang merupakan zat biokimia dan berfungsi melindungi diri dari kompetisi antar spesies serta dapat menghambat pertumbuhan jenis tanaman lain di sekitarnya (Nahdi dan Darsikin, 2014). Alelopati mengandung senyawa fenolik antara lain tanin dan flavonoid yang mampu menghambat perkecambahan dan pertumbuhan tumbuhan (Sumi dan Linda, 2018). Alelopati pada tanaman adalah proses biologis dimana tanaman melepaskan biokimia yang mempengaruhi perkecambahan, pertumbuhan dan reproduksi tanaman lain. Biokimia ini dapat dilepaskan ke lingkungan melalui daun, bunga, biji, kulit kayu dan ranting, penguapan serta dari tanah, melalui dekomposisi residu tanaman dan eksudasi akar. Senyawa alelokimia dapat ditemukan diseluruh bagian tanaman, tetapi tempat penyimpanan terbesar senyawa ini biasanya berlokasi di akar dan daun (Djazuli, 2011). Sebagian besar senyawa alelopati yang dihasilkan melalui eksudasi akar adalah berupa asam fenolat. Senyawa alelopati dapat dikelompokkan pada 5 jenis, yaitu : asam fenolat, koumarat, terpinoid, flafinoid, dan scopulaten (penghambat fotosintesis).

Pengamatan yang dilakukan di Bukit Penghijauan Mandor Kabupaten Landak, ditemukan berbagai keanekaragam jenis tumbuh di bawah tegakan Acacia mangium. Ini menunjukkan bahwa masih ada berbagai jenis tanaman yang tidak terhambat pertumbuhannya di bawah tegakan akasia. Penelitian ini perlu dilakukan untuk mengkaji keanekaragaman jenis tumbuhan bawah, jenis vegetasi apa saja yang dominan dan bisa tumbuh di bawah tanaman Acacia mangium serta mampu beradaptasi dengan kondisi tapak yang diduga mengandung alelopati. Jadi permasalahannya penelitiaan ini berfokus pada berapakah jumlah tumbuhan bawah yang ditemukan.

\section{METODE PENELITIAN}

Penelitian ini dilaksanakan di Bukit Penghijauan Mandor Kabupaten Landak. Waktu penelitian \pm 4 minggu di lapangan dilaksanakan pada bulan Desember sampai Januari 2020. Penelitian ini menggunakan metode survei dengan pengambilan petak contoh kuadrat yang diletakkan secara sistematis. Peletakan petak tersebut dilakukan cara purposive sampling yaitu pada areal yang ada tanaman akasia. Petak contoh pengamatan yang digunakan ukuran $10 \mathrm{~m}$ x $10 \mathrm{~m}$, kemudian dibagi ke dalam 25 plot contoh ukuran $2 \mathrm{~m} \mathrm{x} 2 \mathrm{~m}$. Penelitian ini menggunakan sebanyak 10 petak sehingga terdapat 250 plot pengamatan dan dengan luas area penelitian 0,1 ha. 


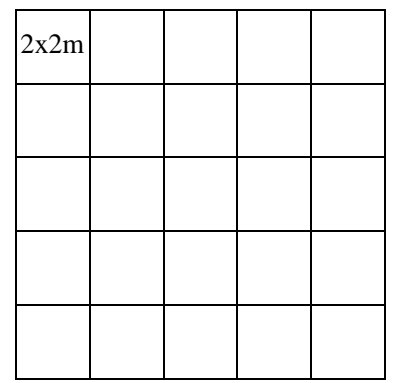

Gambar 1. Desain unit petak contoh (Squares unit design)

\section{Analisis Data}

Data yang telah dikumpulkan dalam penelitian ini, ditabulasi dan dianalisis secara deskriptif kuantitatif dengan menggunakan rumus sebagai berikut :

1. Indeks Nilai Penting (Soerianegara dan indrawan, 2008) : INP = Kerapataan relatif $(\mathrm{KR})+$ Frekunsi relatif $(\mathrm{FR})$

2. Indeks Dominasi (C)

Indeks dominsi menggambarkan pola dominansi jenis dalam suatu komunitas. nilai indeks yang tertinggi adalah 1, yang menunjukkan bahwa tegakan tersebut dikuasai oleh satu jenis atau terpusat pada satu jenis. Jika beberapa jenis mendominansi secara bersama-sama maka indeks dominansi akan mendekati nol atau rendah. Indeks dominasi diperoleh dengan menggunakan rumus Simpson (1949) dalam Odum (1993).

$\mathrm{C}=\sum\left(\frac{\mathrm{ni}}{\mathrm{N}}\right)^{2}$

Dimana :

$\mathrm{C}=$ Indeks Dominansi

$\mathrm{ni}=\mathrm{INP}$ jenis $\mathrm{i}$

$\mathrm{N}=$ Total INP

3. Indeks Keanekaragaman (H') ShanonWiener

Penentuan besarnya Keragaman Jenis tumbuhan dilakukan analisis dengan menggunakan Indeks Keanekaragaman yang dipilih dalam analisis komunitas mengacu pada metode Shanon-Wiener (1949) dalam Indriyanto (2006).

$H^{\prime}=-\Sigma\left[\frac{\mathrm{n} . \mathrm{i}}{\mathrm{N}} \log \frac{\mathrm{n} . \mathrm{i}}{\mathrm{N}}\right]$

Dimana :

$\mathrm{H}^{\prime}=$ Indeks Keanekaragaman ShannonWiener

n.i $=$ Nilai Penting dari spesies

$\mathrm{N}=$ Total INP

Kriteria nilai indeks keanekaragaman menurut ShannonWiener dalam Fachrul (2008) Rendah jika $\mathrm{H}^{\prime}<1$, Sedang jika H' 1-3 dan Tinggi jika $\mathrm{H}^{\prime}>3$

4. Indeks Kekayaan Jenis $\left(R_{I}\right)$

Untuk mengetahui Indeks Kekayaan Jenis digunakan rumus Margallef (1958) dalam Hilwan et al. (2013)

$\mathrm{R}_{1}=\frac{(\mathrm{S}-1)}{(\operatorname{In}(\mathrm{N}))}$

Dimana :

$\mathrm{R}_{1}=$ Indeks Kekayaan

$\mathrm{S}=$ Jumlah jenis yang ditemukan

$\mathrm{N}=$ Jumlah total individu

Kriteria nilai indeks kekayaan menerut Margallef dalam Hilwan et al. (2013) $R_{I} \quad<\quad 3,5$ menunjukkan kekayaan jenis yang tergolong rendah, $R_{I}=3,5-5,0$ menunjukkan Kekayaan Jenis tergolong 
sedang, sedangkan nilai $R_{I}>5,0$ menunjukkan kekayaan jenis yang tergolong tinggi.

\section{HASIL DAN PEMBAHASAN}

\section{Jumlah Jenis Tumbuhan Bawah}

Berdasarkan hasil penelitian yang
Kabupaten Landak, ditemukan 21 jenis tumbuhan bawah. Data jenis tumbuhan yang ditemukan dapat dilihat pada Tabel 1 dan banyaknya jumlah individu tumbuhan yang diamati di lapangan disajikan pada Gambar 2. dilakukan di Bukit Penghijauan Mandor

Tabel 1. Data jenis tumbuhan bawah yang ditemukan di Bukit Penghijauan Mandor Kabupaten Landak (Data on species of understorey that be discovered in Bukit Penghijauan Mandor Landak District).

\begin{tabular}{clll}
\hline No & \multicolumn{1}{c}{ Nama Lokal } & \multicolumn{1}{c}{ Famili } & \multicolumn{1}{c}{ Nama latin } \\
\hline 1 & Cengkodok & Melastomataceae & Melastoma malabathricum \\
2 & Lengkan & Moraceae & Ficus grossularioides \\
3 & Putri malu & Fabaceae & Mimosa pudica \\
4 & Maniram hijau & Euphorbiaceae & Phyllantthus niruri L. \\
5 & Paku resam & Gleicheniaceae & Gleichenia linearis Burm Clarke \\
6 & Rumput bede & Poaceae & Paspalum conjugatum Berg. \\
7 & Rumput tembaga & Poaceae & Ischaemum muticum \\
8 & Rumput rija-rija & Cyperaceae & Scleria sumatrensis Retz \\
9 & Sisik betook & Fabaceae & Desmodium triflorum \\
10 & Rambusa & Melastomataceae & Passiflora foetida L. \\
11 & Ara sunsang & Acanthaceae & Asystasia gangetica \\
12 & Manyam & Teaceae & Eurya nitida Korth \\
13 & Rumput setawar & Rubiaceae & Borreria latiflora \\
14 & Nanas hutan & Bromiliaceae & Ananas comosus \\
15 & Krinyuh & Asteraceae & Chromolaena odorata L. \\
16 & Paku pedang & Driopteridaceae & Nephrolepis Falcata Cap. C. Chr \\
17 & Cangkok & Phyllanthaceae & Breynia sp. \\
18 & Paku miding & Blechnaceae & Stenochlaena palustri (Burm) Bedd \\
19 & Paku hata & Lygodiaceae & Lygodium sp. \\
20 & Sumiang & Anisophylleaceae & Anisophyllea disticha \\
21 & Akar rambat & Rubiaceae & Psychotria sarmentosoides \\
\hline
\end{tabular}

Pada tanaman A. mangium jenis bede (Paspalum conjugatum) dengan tumbuhan bawah yang banyak ditemukan di Bukit Penghijauan jumlah 201 individu dan akar rambat Mandor, seperti yang disajikan pada Gambar 2 adalah paku resam (Gleichenia linearis Burm Clarke) dengan jumlah 306 individu. Jenis lainnya yang banyak adalah rumput (Psychotria sarmentosoides) dengan jumlah 150 individu. Banyaknya jenis paku resam yang ditemukan dibawah tanaman A. mangium karena : (1) naungan A. mangium cukup terbuka, berlimpahnya cahaya matahari akan 
memicu pertumbuhan dan perkembangan tumbuhan bawah yang bersifat intoleran (Hilwan et al. 2013), (2) memiliki toleransi yang tinggi untuk

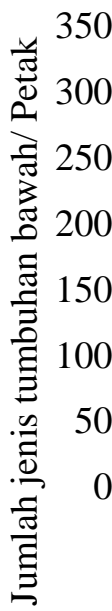

\section{6}

201 dapat tumbuh dan berkembang pada tanah masam dan terhadap tapak yang diduga mengandung alelopati (Hasibuan et al. 2016).

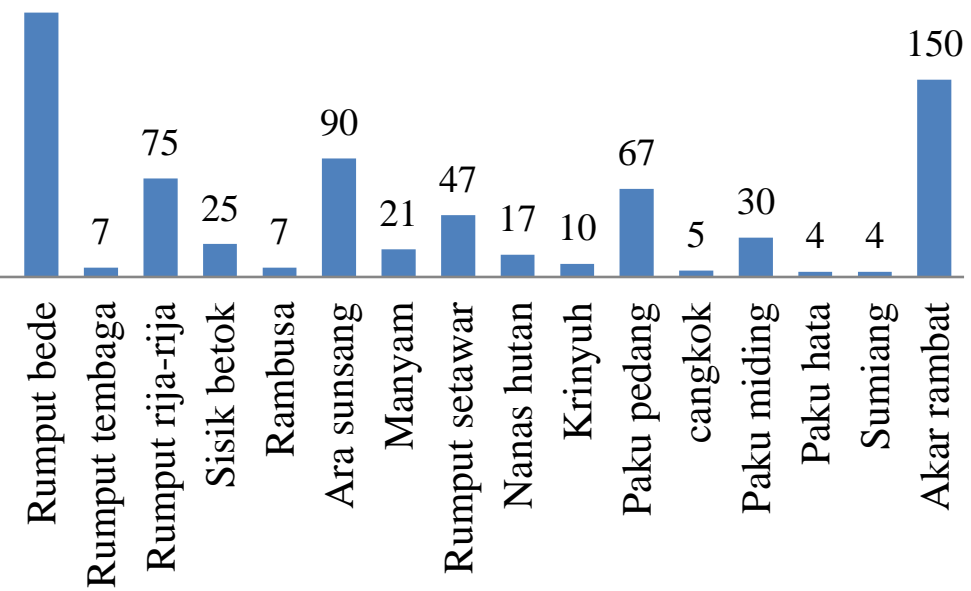

Jenis tumbuhan bawah

Gambar 2. Jumlah individu tumbuhan bawah yang terdapat di bawah tegakan $A$. mangium (The amount of individual understory that be under A. mangium stands).

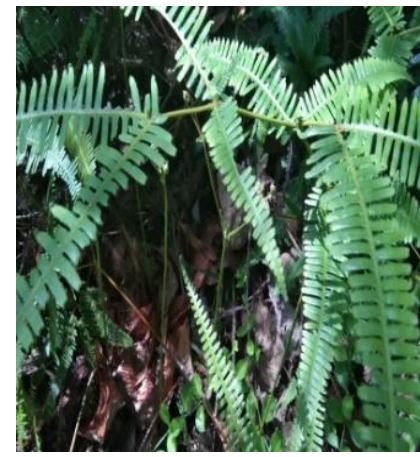

Paku resam (Gleichenia linearis)

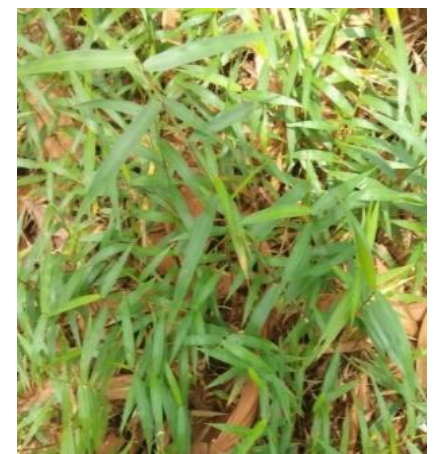

Rumput bede (Paspalum conjugatum)

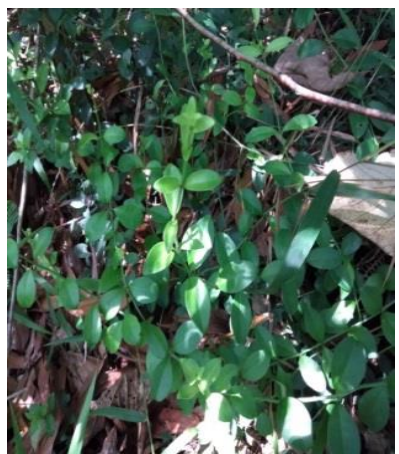

Akar rambat (Psychotria sarmentosoides)

Gambar 3. Jenis tumbuhan bawah yang banyak terdapat di bawah tegakan $A$. mangium (Species of understorey that are much under A. mangium stands).

Jenis yang jumlahnya sangat sedikit adalah paku hata (Lygodium sp.) dan sumiang (Anisophyllea disticha) masing-masing hanya 4 individu.
Jumlah jenis yang sedikit ini diduga karena memiliki batas tolerasi yang sempit terhadap fakto-faktor lingkungan terutama intensitas, yang dianggap 
dianggap sebagai salah satu faktor penting dalam pertumbuhan tumbuhan bawah (Hilwan et al. 2013).

2. Analisis Keanekaragaman Jenis tumbuhan bawah

Analisis data dilakukan untuk mengetahui keanekaragaman jenis tumbuhan bawah di Bukit Penghijauan Mandor dengan parameter Indeks Nilai Penting (INP) dapat dilihat pada Tabel 2 sedangkan Indeks Dominasi (C), Indeks Keanekaragamaan Jenis (H'), Indeks Kekayaan Jenis $\left(R_{1}\right)$ secara jelas dapat dilihat pada Tabel 3.

Tabel 2. Indeks Nilai Penting (INP) Tumbuhan Bawah di Bukit Penghijauan Mandor (Importance Value Index (INP) understorey in Bukit Penghijauan Mandor).

\begin{tabular}{|c|c|c|c|c|c|c|}
\hline No & Nama Latin & $\mathbf{K}$ & KR (\%) & $\mathbf{F}$ & FR $(\%)$ & INP \\
\hline 1 & Melastoma malabathricum & 300 & 2,65 & 0,6 & 5,77 & 8,42 \\
\hline 2 & Ficus grossularioides & 100 & 0,88 & 0,4 & 3,85 & 4,73 \\
\hline 3 & Mimosa pudica & 100 & 0,88 & 0,2 & 1,92 & 2,81 \\
\hline 4 & Phyllantthus niruri (L.) & 150 & 1,33 & 0,2 & 1,92 & 3,25 \\
\hline 5 & Gleichenia linearis Burm Clarke & 3060 & 27,1 & 1 & 9,62 & 36,7 \\
\hline 6 & Paspalum conjugatum Berg. & 2010 & 17,8 & 1 & 9,62 & 27,4 \\
\hline 7 & Ischaemum muticum & 70 & 0,62 & 0,2 & 1,92 & 2,54 \\
\hline 8 & Scleria sumatrensis Retz & 750 & 6,62 & 0,7 & 6,73 & 13,4 \\
\hline 9 & Desmodium triflorum (L.) Dc & 250 & 2,21 & 0,2 & 1,92 & 4,13 \\
\hline 10 & Passiflora foetida $\mathrm{L}$ & 70 & 0,62 & 0,5 & 4,81 & 5,43 \\
\hline 11 & Asystasia gangetica & 900 & 7,96 & 0,7 & 6,73 & 14,7 \\
\hline 12 & Eurya nitida Korth & 210 & 1,86 & 0,7 & 6,73 & 8,59 \\
\hline 13 & Borreria latiflora & 470 & 4,16 & 0,6 & 5,77 & 9,92 \\
\hline 14 & Ananas comosus & 170 & 1,5 & 0,2 & 1,92 & 3,43 \\
\hline 15 & Chromolaena odorata (L.) & 100 & 0,88 & 0,3 & 2,88 & 3,77 \\
\hline 16 & Nephrolepis Falcata Cap. C. Chr & 670 & 5,92 & 0,5 & 4,81 & 10,7 \\
\hline 17 & Breynia sp. & 50 & 0,44 & 0,5 & 4,81 & 5,25 \\
\hline 18 & Stenochlaena palustri (Burm) Bedd & 300 & 2,65 & 0,5 & 4,81 & 7,46 \\
\hline 19 & Lygodium sp. & 40 & 0,35 & 0,3 & 2,88 & 3,24 \\
\hline 20 & Anisophyllea disticha & 40 & 0,35 & 0,3 & 2,88 & 3,24 \\
\hline \multirow[t]{2}{*}{21} & Psychotria sarmentosoides & 1500 & 13,3 & 0,8 & 7,69 & 21 \\
\hline & Total & 11310 & 100 & 10,4 & 100 & 200 \\
\hline
\end{tabular}

Berdasarkan indeks nilai penting (INP) dari masing-masing jenis tumbuhan bawah yang ditemukan pada seluruh petak pengamatan di Bukit Penghijauan Mandor Kabupaten Landak jenis paku resam memiliki tingkat penguasaan paling tinggi dengan nilai INP sebesar 36,7\% dengan jumlah individu sebanyak 3060/ha. Hal ini dibuktikan dengan ditemukannya jenis tumbuhan paku ini pada seluruh petak pengamatan, tingginya nilai INP jenis ini menjadi penentu komonitas (ekosistem) tumbuhan bawah di bawah tanaman akasia. Jenis tumbuhan bawah lain yang tumbuh dibawah akasia dengan INP yang cukup tinggi adalah rumput bede $(27,4 \%)$ dengan jumlah individu 2010/ha dan akar rambat (21\%) dengan jumlah individu 1500/ha. Hal ini sesuai dengan penelitian Indriyani et al. (2017) menyebutkan 
bahwa nilai INP tertinggi pada semua jenis tumbuhan bawah yaitu rumput signal (Brachiaria decumbens ) dengan jumlah INP sebesar $(19,55 \%)$ dengan jumlah individu 29833,3/ha. Jenis tumbuhan bawah tersebut yang memiliki Indeks nilai penting tertinggi mengidentifikasikan bahwa jenis-jenis inilah yang mempengaruhi kestabilan ekosistem secara keseluruhan.

Tabel 3. Indeks Dominasi (C), Indeks Keanekaragamaan Jenis (H') Dan Indeks Kekayaan Jenis $\left(R_{1}\right)$, Tumbuhan Bawah (Dominance Index $(C)$, Species Diversity Index $(H)$ and Species Richness Index $\left(R_{1}\right)$, understoreys).

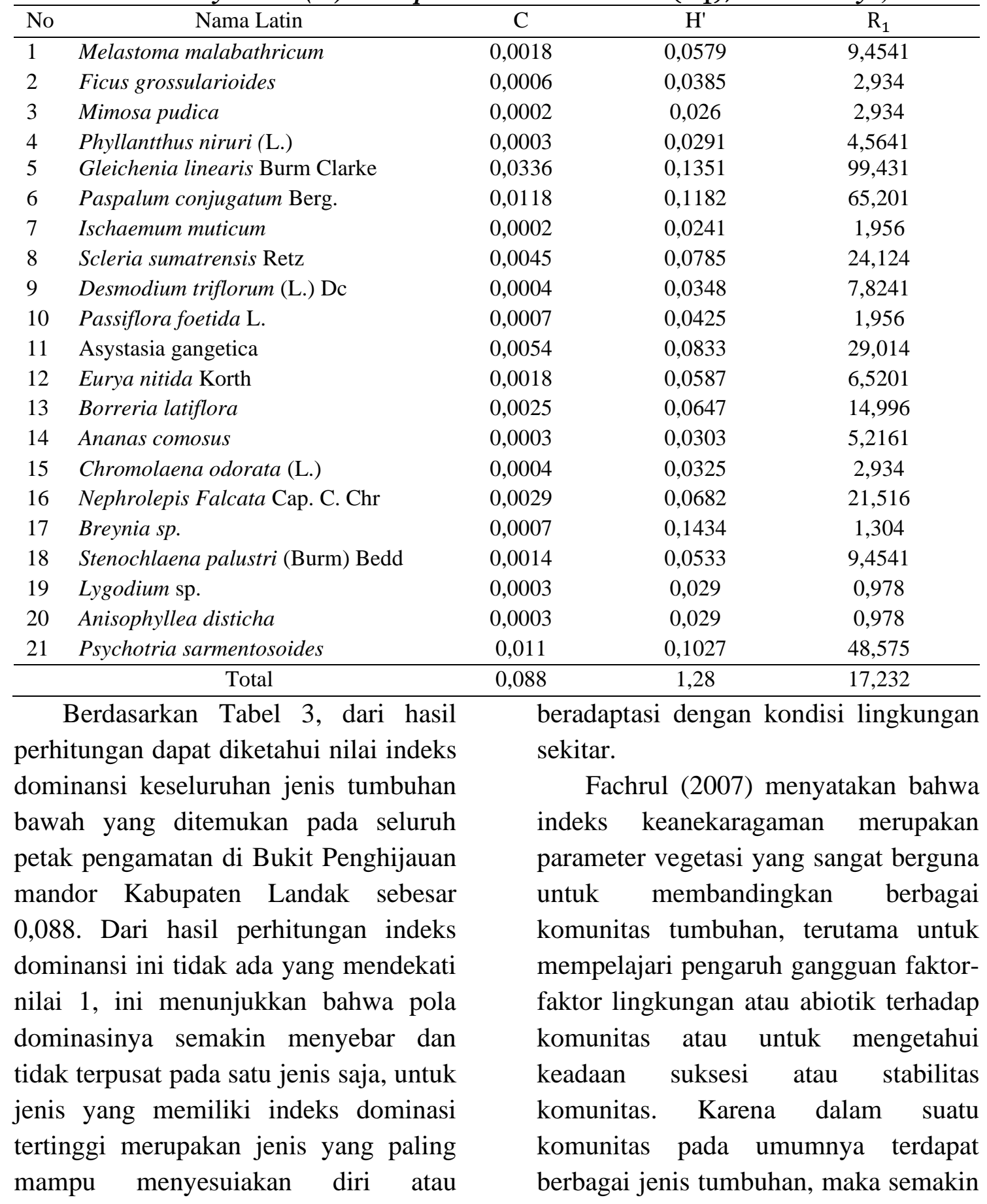


tua atau semakin stabil keadaan suatu komunitas, makin tinggi. Dari hasil perhitungan, dapat diketahui bahwa indeks nilai keanekaragaman jenis ( $\left.\mathrm{H}^{\prime}\right)$ keseluruhan jenis tumbuhan yang ditemukan pada seluruh petak pengamatan di lokasi penelitian sebesar 1,28. Nilai keanekaragaman jenis tumbuhan bawah tersebut tergolong sedang karena H'1-3. Hal ini dapat dibandingkan dengan penelitian yang dilakukan oleh Destaranti et al. (2017) menyebutkan bahwa indeks keanekaragaman tumbuhan bawah di wilayah dataran rendah (RPH Kalirajut) sebesar 1,269. Banyak alasan atau faktor mempengaruhi dari keanekaragaman yang terjadi. Meskipun demikian tumbuhan bawah yang terdapat di lokasi penelitian tumbuh menyebar hampir menyeluruh baik di tepi kawasan maupun di dalam kawasan. Kategori tersebut mengartikan bahwa komunitas sedang menuju pada kondisi yang stabil.

Hasil analisis kekayaan jenis $\left(R_{1}\right)$ tumbuhan bawah yang ditemukan di lokasi penelitian dapat dilihat pada Tabel 3. Berdasarkan hasil analisis pada Tabel 3 ternyata nilai indeks kekayaan jenis 17,232 atau lebih besar dari 5 . Indeks nilai kekayaan lebih besar dari 5 menunjukkan bahwa kekayaan jenis tumbuhan bawah yang tumbuh di bawah tanaman A. mangium tergolong tinggi (Maggurran, 1988).

Hasil dari penelitian Jenis yang jumlahnya sangat sedikit adalah paku hata (Lygodium sp.) dan sumiang (Anisophyllea disticha) masing-masing hanya 4 individu. Jumlah jenis yang sedikit ini diduga karena memiliki batas tolerasi yang sempit terhadap faktofaktor lingkungan terutama intensitas cahaya dan tanah (Hilwan et al. 2013). Sedangkan jenis tumbuhan bawah yang dominan adalah paku resam, rumput bede dan akar rambat. Dari ketiga jenis yang dominan ditemukan, terdapat dua jenis yang selalu dijumpai pada seluruh petak pengamatan yaitu paku resam jenis ini termasuk dalam famili Gleicheniaceae atau golongan pakupakuan dan rumput dari famili Poaceae atau golongan rerumputan.

Dominannya jenis paku resam selain dari memiliki daya adaptasi lingkungan yang tinggi juga mampu menyerap racun di sekitar tempat tumbuhnya dan bersifat invasif di beberapa tempat yang menyebabkan tumbuhan lain terhambat pertumbuhannya (Hasibuan et al. 2016). Tumbuhan ini juga sangat menyukai habitat yang terbuka yang langsung terkena sinar matahari. Kondisi naungan sangat mempengaruhi masuknya cahaya matahari ke dalam tegakan. Hilwan et al. (2013) menyatakah bahwa penutupan tajuk atau naungan sangat memengaruhi pertumbuhan dan banyaknya jenis tumbuhan bawah. Hasil pengamatan di lapangan menunjukkan bahwa kondisi naungan tajuk pada tanaman A. mangium cukup terbuka. Sehingga paku resam tumbuh subur dan mendominasi di Bukit Penghijauan Mandor Kalimantan Barat.

Jenis rumput bede biasanya hidup pada daerah yang tidak terlalu kering, di 
bawah tegakan hutan sekunder, di pinggir jalan dan di tempat lembab yang masih terkena sinar matahari. Dari pengamatan di lapangan kondisi tempat tumbuhnya cukup kering dan sangat banyak dijumpai di pinggiran jalan yang banyak sinar mataharinya. Jenis ini juga dapat tumbuh pada tanah yang kurang nutrisi, kering dan yang memiliki keasaman diatas rata-rata, yang diduga dapat tumbuh subur dan mendominasi di Bukit Penghijauan Mandor Kabupaten Landak.

Dominannya kedua jenis ini membuktikan bahwa jenis paku resam dan rumput bede memiliki tingkat tolerasi tinggi terhadap faktor-faktor lingkungan yang berpengaruh, terutama intensitas cahaya dan tanah. Faktor lingkungan yang berpengaruh terhadap tumbuhan bawah dikemukakan pada tabel Tabel 4.

Tabel 4. Hasil pengamatan Faktor Lingkungan di bawah tegakan A. mangium (The result of observation of environmental factors under A. mangium stands)

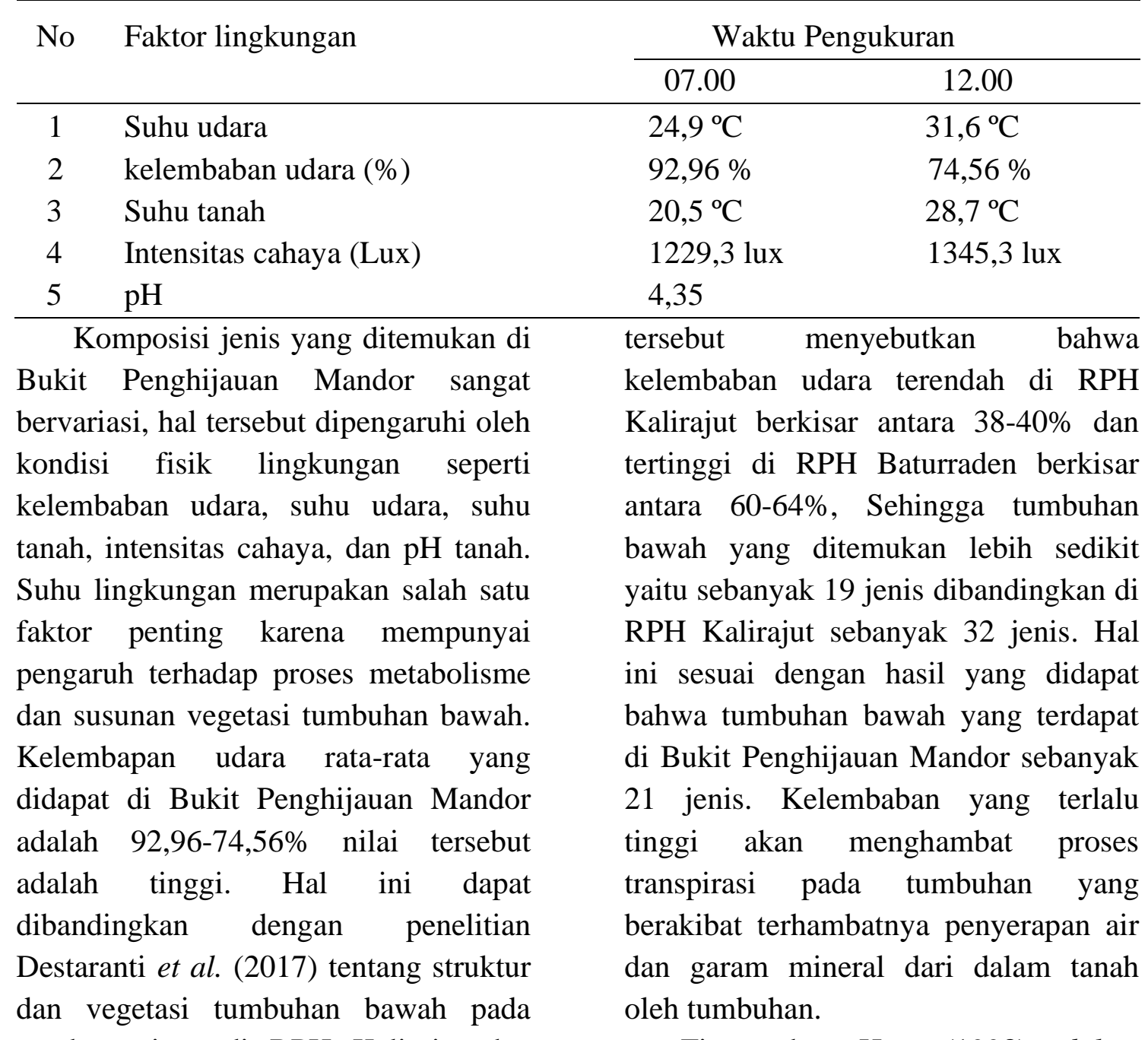
tegakan pinus di RPH Kalirajut dan RPH baturraden banyumas. Penelitian

Fitter dan Hay (1998) dalam Hilwan et al. (2013) menyatakan bahwa 
salah satu kondisi lingkungan yang paling berpengaruh terhadap pertumbuhan tumbuhan di bawah tegakan antara lain cahaya matahari dan naungan. Tegakkan A. mangium mempunyai naungan yang cukup terbuka, sehingga intensitas cahaya yang masuk di lantai hutan relatif tinggi (1229,3-1345,3 lux). Hal ini mempengaruhi besarnya suhu udara, kelembaban udara, dan suhu tanah.

$\mathrm{pH}$ tanah yang didapatkan dalam pengukuran parameter di lokasi penelitian adalah tergolong asam (4,35). Keasaman tanah yang tinggi sangat menentukan semua reaksi yang ada, tingginya $\mathrm{pH}$ tanah maka keragaman jenisnya akan semakin rendah. Selain $\mathrm{pH}$ tanah alelopati kemungkinan juga berpengaruh terhadap perkembangan dan pertumbuhan tumbuhan bawah. Pengaruh alelopati bersifat selektif, yaitu berpengaruh terhadap jenis organisme tertentu, namun tidak terhadap organisme lain (Ismaini, 2015). Pada kondisi yang lain, senyawa yang dilepaskan dari guguran daun atau residu tumbuhan mungkin bersifat alelopati tetapi tumbuhan tidak menunjukan pengaruh alelopati pada lingkungannya. Rumput bede, paku resam dan akar rambat adalah jenis yang dapat tumbuh sehingga banyak ditemukan di Bukit Penghijauan Mandor Kabupaten Landak.

\section{KESIMPULAN}

Tingkat keanekaragaman jenis tumbuhan bawah di bawah tegakan $A$. mangium di Bukit Penghijauan Mandor adalah sedang $(1,28)$. Tumbuhan bawah yang ditemukan sebanyak 21 jenis dengan jenis yang memiliki nillai INP tertinggi yaitu : cengkodok (Melastoma malabathricum), rumput bede (Paspalum conjugatum Berg), paku resam (Gleichenia linearis Burm Clarke), rumput rija-rija (Scleria sumatrensis Retz) dan akar rambat (Psychotria sarmentosoides). Jenis yang dominan tumbuh di bawah tegakan $A$. mangium adalah paku resam (Gleichenia linearis Burm Clarke) sebanyak 360 individu, rumput bede (Paspalum conjugatum Berg) sebanyak 201 individu dan akar rambat (Psychotria sarmentosoides) sebanyak 150 individu.

\section{DAFTAR PUSTAKA}

Djazuli M. 2011. Alelopati Pada Beberapa Tanaman Perkebunan dan Teknik Pengendalian Serta Prospek Pemanfaatannya. Jurnal Perspektif. 10(1) : 44-50.

Destaranti N, Sulistyani, Yani E. 2017. Struktur dan Vegetasi Tumbuhan Bawah Pada Tegakan Pinus Di RPH Kalirajut dan RPH Baturraden Banyumas. Jurnal Scripta Biologica. 4(3) : 155-160.

Fachrul FM. 2008. Metode Sampling Bioekologi. Jakarta : PT Bumi Aksara.

Hasibuan H, Rizalinda, Rusmiyanto E.P.W. 2016. Inventarisasi Jenis Paku-Pakuan (Pteridophyta) di Hutan Sebelah Darat Kecamatan Sungai Ambawang Kalimantan Barat. Jurnal Untan. 5(1) : 46-58.

Hilwan, Iwan, Mulyana D, Pananjung WG. 2013. Keanekaragaman Jenis Tumbuhan Bawah Pada Tegakan Sengon Buto (Enterolobium 
cyclocarpum Griseb) dan Trembesi (Samanea saman Merr.) Di Lahan Pasca Tambang Batubara PT Kitadin, Embalut, Kutai Kartanegara, Kalimantan Timur. Jurnal Silvikultur Tropika. 4(1) : 6-10.

Indriyani L, Flamin A, Erna. 2017. Analisis Keanekaragaman Jenis Tumbuhan Bawah Di Hutan Lindung Jompi (Kelurahan Wali Kecamatan Watopute Kabupaten Muna Sulawesi Tenggara). Jurnal Ecogreen. 3(1) : 49-58.

Indriyanto. 2006. Ekologi Hutan. Jakarta : Bumi Aksara.

Ismaini L. 2015. Pengaruh Alelopati Tumbuhan Invasif (Cidemia hirta) Terhadap Germinasi Biji Tumbuhan Asli (Impatiens platypetala). Jurnal Pros Sem Nas Masy Biodiv Indon. 1(4) : 834837

Magurran AE. 1988. Ecological Diversity and Its Measurenment. Princeton NJ: Princeton University Press.

Nahdi MS, Darsikin. 2014. Distribusi dan Kemelimpahan Spesies Tumbuhan Bawah pada Naungan Pinus mercusii, Acacia auriculiformis dan Eucalyptus alba di Hutan Gama Giri Mandiri, Yogyakarta. Jurnal Natur Indonesia. 16(1) : 33-41.

National Research Council. 1983. Mangium and other fast-growing Acacias for the humid tropics. Washington, DC, AS : National Academy Press.

Odum EP. 1993. Dasar - Dasar Ekologi. Edisi Bahasa Indonesia.Yogyakarta : Gajah Mada University. Press.

Soerianegara I, dan A Indrawan. 2008. Ekologi Hutan Indonesia. Bogor. Laboratorium Ekologi Hutan. Fakultas Kehutanan. Institud Pertanian Bogor.

Sumi, Linda R, Rousdy DW. 2018. Aktivitas Ekstrak Metanol Daun Akasia (Acacia mangium Willd) Terhadap Perkecambahan dan Pertumbuhan Maman Ungu (Cleome rutidospermae D.C) dan Rumput Grinting (Cynodon dactylon L. Pers). Jurnal Protobiont. 7(3) : 90-96.

Sutedjo, Warsudi. 2017. Menakar Sifat Invasif Spesies Akasia Mangium (Acacia mangium willd) Di Hutan Penelitian dan Pendidikan Bukit Soeharto. Jurnal Hutan Tropis. 1(1) : 82-89. 